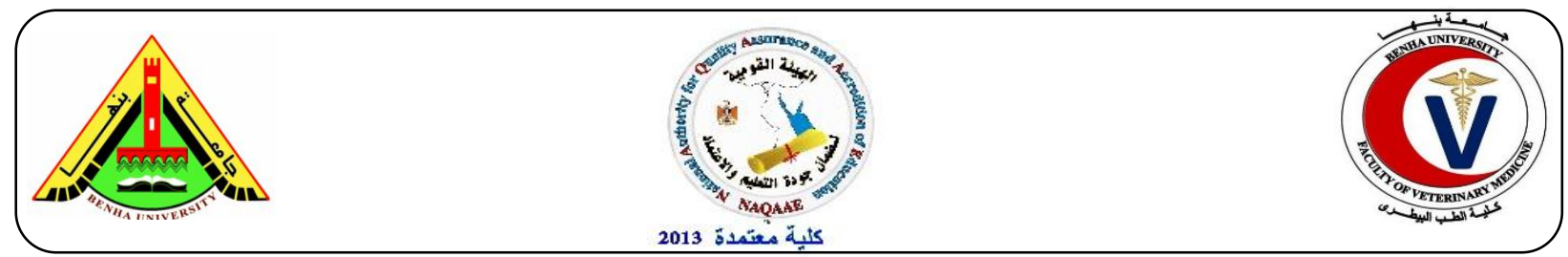

\title{
Detection of adulteration in some traditional processed meat products with equine meat
}

${ }^{1}$ Faten S. Hassanin; ${ }^{2}$ Reham A. Amin; ${ }^{3}$ Nahla A. Abou-Elroos; ${ }^{3}$ Sameh M. Helmy

${ }^{\prime}$ Food Hygiene Dep., Fac. Vet. Med. Benha Univ., ${ }^{2}$ Food Hygiene Dep., Face. Vet. Med. Benha Univ., ${ }^{3}$ Animal Health Research Institute - "Shebin El-Kom” branch.

\section{A B S T R A C T}

Sixty random samples of minced meat and sausage each weighting $250 \mathrm{gm}$ (30 of each) were collected from different butchers (15 of each), processing plants (15 of each), in Menofiya and Gharbiya governorates for detection of their adulteration by illegal substitution with cheaper or prohibited meat. Application of PCR technique for detection of adulteration of such products purchased from butcher shops was given, 11 samples of minced meat (73.33\%) and 11 samples of sausage $(73.33 \%)$ were not adulterated, respectively. while 4 samples (26.67\%) of minced meat were adulterated ( 3 samples $20 \%$ adulterated by intermixed cattle and equine meat and 1 sample $6.67 \%$ adulterated by pure equine meat) and 4 samples $(26.67 \%)$ of sausage were adulterated (1 sample samples $6.67 \%$ adulterated by intermixed cattle and equine meat and 3 samples $20 \%$ adulterated by pure equine meat), respectively. Concerning minced meat and sausage samples purchased from processing plants was given, 15 samples (100\%) and 13 samples (86.67\%) were not adulterated, respectively, $(0 \%)$ of minced meat were adulterated and 2 samples $(13.33 \%)$ of sausage were adulterated ( 1 sample samples $6.67 \%$ adulterated by intermixed cattle and pig meat and 1 samples $6.67 \%$ adulterated by intermixed cattle and equine meat), respectively. Finally, the obtained data in the current study, PCR technique was the most rapid and accurate method for detection and identification of the meat related to animal species as compared with Precipitation test.

Keywords: Adulteration, Multiplex PCR, minced meat, sausage, equine meat

(BVMJ, 34 (1), 2018)

\section{INTRODUCTION}

Meat species adulteration is a worldwide problem which violates food labeling laws. Thus, determination of the species of the meat components in meat products is an essential task in food hygiene (Ayman, 2011) meat adulteration in ground and comminuted products has been a widespread problem in retail markets.

Consumers rarely have a problem identifying fresh meat when bought at markets or in shops, the particular color and shape of beef can be distinguished from pork or equine when the meat is fresh.

Today, many consumers are concerned about the meat they eat and accurate 
labelling is important to inform consumer choice. The choice of one product over another can reflect aspects of lifestyle (e.g. vegetarianism and organic food), religion (e.g. absence of pork from some diets), diet and health concerns (e.g. absence of allergens). In addition, accurate labelling is important to support fair-trade. Additional descriptive label information can be added as a consequence of branding, product marketing purposes and regulations (Ballin, 2010). Meat species specification is an utmost important field of food forensics. It is more challenging and revolutionary task to ensure the quality of meat and help in conservation of law existing in different countries (Singh and Sachan, 2009).

According to the food law, the species' names of meats used to prepare the meat products have to be presented on the label of the product. Moreover, selling other meat species with false labels to get more profit is held as imitation and prohibition according to the foodstuff laws.

The PCR was applied to identify six meat (cattle, pig, chicken, sheep, goat and horse) as raw materials for products. By mixing seven primers in appropriate ratios, species-specific DNA fragments could be identified by only one multiplex PCR. A forward primer was designed on conserved DNA sequence in the mt cyt $b$ gene and reverse primers on species- specific DNA sequences for each species (Anderson et al., 1982, Desjardins and Morals, 1991 and Irwin et al., 1991).

Presence of target DNA was successfully identified for species tested, and the amplification was not affected by spice addition or the cooking process.

Similar researches were done in fermented sausages (Kesmen, et al., 2006) and cooked sausages (Kesmen et al., 2007). The extraction method is less timeconsuming and technically demanding than the one previously described by Matsunga et al., (1999).

Therefore, this work was planned out to investigate most reliable and sensitive methods suitable for routine analysis for identification of meat species in adulterated meat products.

\section{MATERIAL AND METHODS}

\subsection{Collection of the samples:}

Actually, 60 random samples of minced meat and sausage each weighting $250 \mathrm{gm}$ (30 of each) were collected from different butchers (15 samples of each product), processing plants (15 samples of each product), respectively, in Menofiya and Gharbiya governorates for detection of their adulteration by illegal substitution with cheaper or prohibited meat. All collected samples were subjected to the following examinations:

\subsection{Polymerase Chain Reaction (PCR):}

\subsubsection{Primer sequences of species specific genes used for PCR identification system:}

Application of PCR for identification of cyt $b$ genes for differentiation of meats of different animal species was performed essentially by using primers (Pharmacia Biotech) as shown in the following table: 


\begin{tabular}{|c|c|c|c|c|}
\hline $\begin{array}{l}\text { Animal } \\
\text { Spp. }\end{array}$ & $\begin{array}{l}\text { Target } \\
\text { gene }\end{array}$ & Oligonucleotide sequence $\left(5^{\prime} \rightarrow 3^{\prime}\right)$ & $\begin{array}{l}\text { Product } \\
\text { Size (bp) }\end{array}$ & References \\
\hline $\mathrm{SIM}^{*}$ & cyt b $(F)$ & $\begin{array}{l}\text { 5'CCTCCCAGCTCCATCAAACATCT } \\
\text { CATCTTGATGAAA'3 }^{\prime} \text { ' }\end{array}$ & & \multirow{4}{*}{$\begin{array}{l}\text { Matsunaga et } \\
\text { al., (1999) }\end{array}$} \\
\hline Cattle & cyt b (R) & $\begin{array}{l}\text { 5'CTAGAAAAGTGTAAGACCCGTAA } \\
\text { TATAA'3 }\end{array}$ & 274 & \\
\hline Pig & cyt b (R) & $\begin{array}{l}\text { 5'GCTGATAGTAGATTTGTGATGAC } \\
\text { CGTA ' } 3\end{array}$ & 398 & \\
\hline Equine & cyt b (R) & $\begin{array}{l}\text { 5'CTCAGATTCACTCGACGAGGGTA } \\
\text { GTA ' } 3\end{array}$ & 439 & \\
\hline Dog & $\begin{array}{l}\text { cyt b (F) } \\
\text { cyt b (R) }\end{array}$ & $\begin{array}{c}\text { 5' GGAGTATGCTTGATTCTACAG '3 } \\
\text { 5' AGAAGTGGAATGAATGCC '3 }\end{array}$ & 808 & $\begin{array}{l}\text { Abdulmawjood } \\
\text { et al. (2003) }\end{array}$ \\
\hline
\end{tabular}

SIM* Species-specific oligonucleotide common forward primer

2.2.2.DNA Extraction form the examined meat (Obrovska et al., 2002):

Mitochondrial DNA was extracted from muscle samples. Accurately, $500 \mathrm{mg}$ of muscle tissue was pulverized in liquid $\mathrm{N} 2$ and ground to powder, and mixed with $1 \mathrm{ml}$ Lysis buffer-ST $50 \mathrm{mM}$ Tris-HCI (pH-8.0), 10 mM EDTA (pH-8.0), $100 \mathrm{mM} \mathrm{NaCl}, 150$ $\mu \mathrm{g} / \mathrm{ml}$ proteinase-K and SDS to make final concentration to $2 \%$.

\subsubsection{Amplification reaction of cyt $b$} genes for cattle, pig and equine by multiplex PCR (Jain et al., 2007):

The amplification was performed on a Thermal Cycler (Master cycler, Eppendorf, Hamburg, Germany). PCR amplification was performed in a $25 \mu 1$ reaction volume containing $50 \mathrm{mM} \mathrm{KCI}, 1.5$ $\mathrm{mM} \mathrm{MgCl2}, 200 \mu \mathrm{M}$ dNTP mix, primer mix (4-60 pmol each), 1.25-unit Taq DNA polymerase and $2 \mu \mathrm{l}$ (90 ng template DNA). Species-specific oligonucleotide primers consisting of common forward primer SIM for cattle, equine and pig meat were adopted. These primers were mixed in the ratio of 1: 0.6: 0.6: 2 for SIM: cattle: pork: equine and used together for the multiplex PCR. Amplification conditions consisted of an initial denaturation at $94^{\circ} \mathrm{C}$ followed by 31 cycles at $94^{\circ} \mathrm{C}$ for $30 \mathrm{sec}$, annealing at $60^{\circ} \mathrm{C}$ for $30 \mathrm{sec}$, extension at $72^{\circ} \mathrm{C}$ for 30 sec and final extension at $72^{\circ} \mathrm{C}$ for $10 \mathrm{~min}$ using a thermal cycler. Molecular size markers were indicated on each gel. The products of PCR amplification were analyzed by agarose gel electrophoresis. Amplified DNA fragments were analyzed by $4 \%$ of agarose gel electrophoresis (Applichem, Germany, GmbH) in $5 \mu \mathrm{l} / 100$ $\mathrm{ml}$ TBE buffer stained with ethidium bromide and captured as well as visualized on UV transilluminator. Electrophoretic separation of DNA fragments was done at $100 \mathrm{~V}$ for $60 \mathrm{~min}$. A $100 \mathrm{bp}$ plus DNA Ladder (Qiagen, Germany, GmbH) was used to determine the fragment sizes.

\section{RESULTS}

Application of PCR technique for detection of adulteration of such products purchased from butcher shops was given, 11 samples of minced meat $(73.33 \%)$ and 11 samples of sausage $(73.33 \%)$ were not 
adulterated, respectively. while 4 samples (26.67\%) of minced meat were adulterated (3 samples $20 \%$ adulterated by intermixed cattle and equine meat and 1 sample $6.67 \%$ adulterated by pure equine meat) and 4 samples $(26.67 \%)$ of sausage were adulterated (1 sample samples $6.67 \%$ adulterated by intermixed cattle and equine meat and 3 samples $20 \%$ adulterated by pure equine meat), respectively. Concerning minced meat and sausage samples purchased from processing plants was given, 15 samples (100\%) and 13 samples (86.67\%) were not adulterated, respectively; $(0 \%)$ of minced meat were adulterated and 2 samples $(13.33 \%)$ of sausage were adulterated (1 sample samples $6.67 \%$ adulterated by intermixed cattle and pig meat and 1 samples $6.67 \%$ adulterated by intermixed cattle and equine meat), respectively.

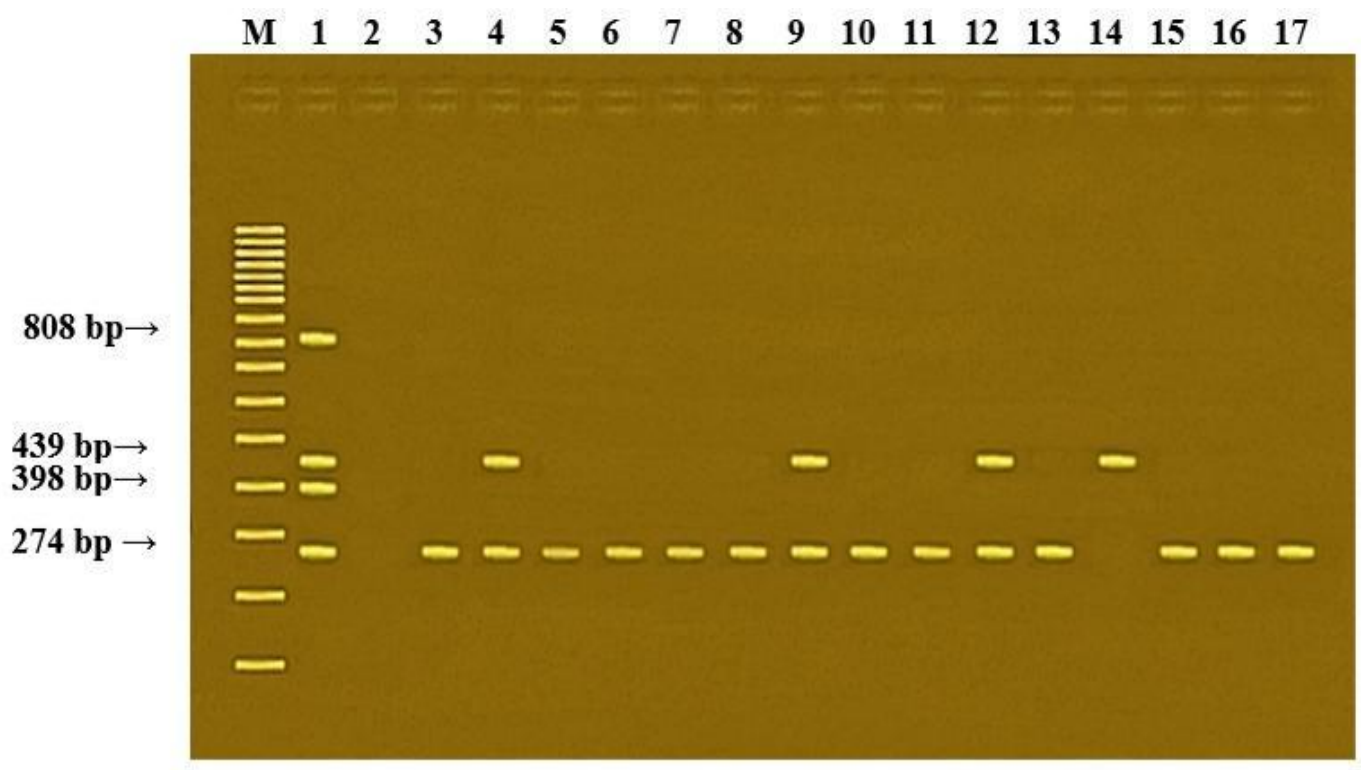

Photograph (1): Agarose gel electrophoresis of multiplex PCR of cyt b gene for cattle (274 bp), pig (398 bp), equine (439 bp) and dog meat (808 bp) for demonstration of minced meat adulteration at butcher shops.

Lane M: 100 bp ladder as molecular size DNA marker.

Lane 1: Control positive for cyt $b$ gene of cattle, pig, equine and dog meats.

Lane 2: Control negative.

Lanes 3, 5, 6, 7, 8, 10,11, 13, 15, 16 \& 17: Pure cattle meat.

Lanes 4, 9 \& 12: Cattle meat intermixed with equine one.

Lanes 14: Pure equine meat. 


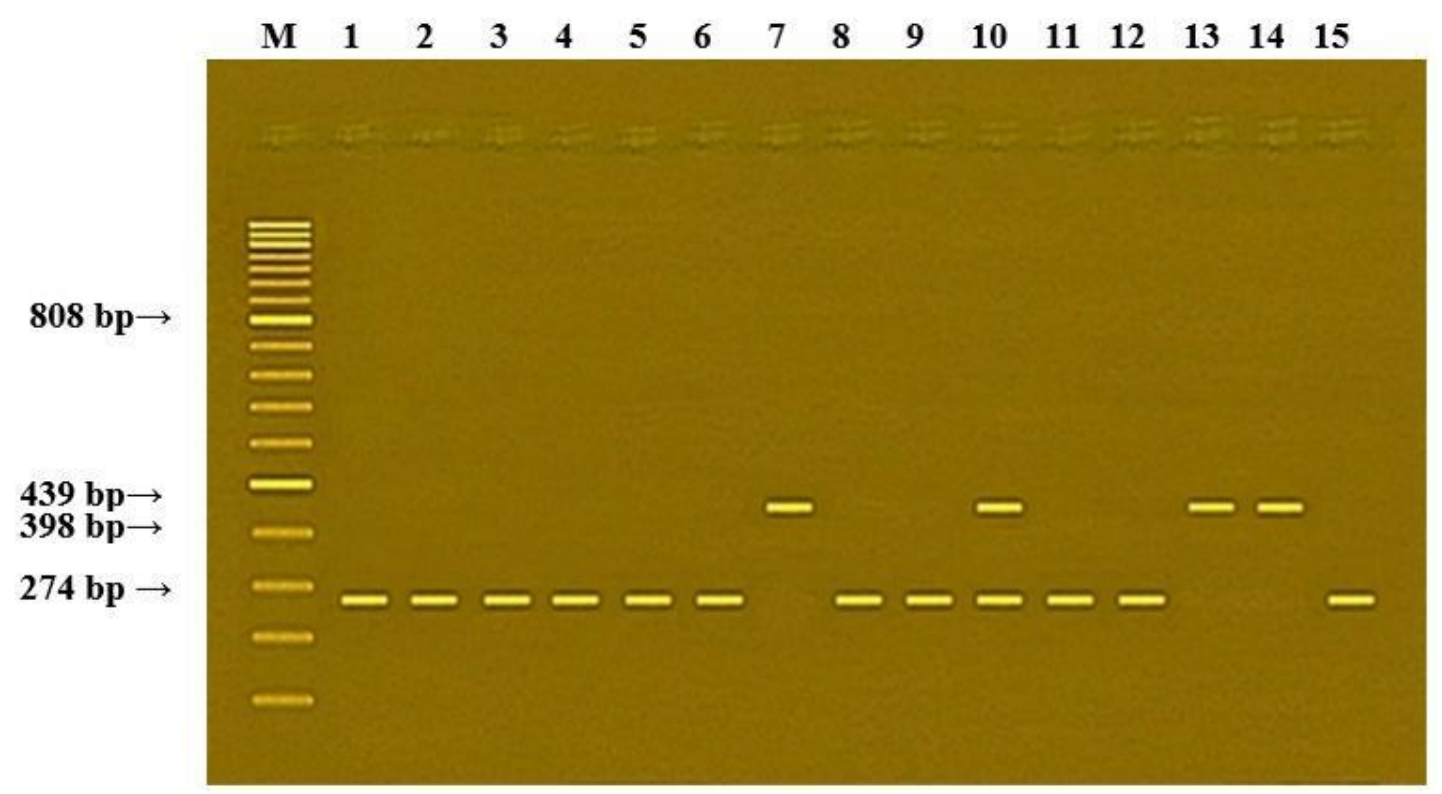

Photograph (2): Agarose gel electrophoresis of multiplex PCR of cyt b gene for cattle (274 bp), pig (398 bp), equine (439 bp) and dog meat (808 bp) for demonstration of sausage adulteration at butcher shops.

Lanes 1, 2, 3, 4, 5, 6, 8, 9, 11, 12 \& 15: Pure cattle meat.

Lane 10: Cattle meat intermixed with equine one.

Lanes 7, 13 \& 14: Pure equine meat.

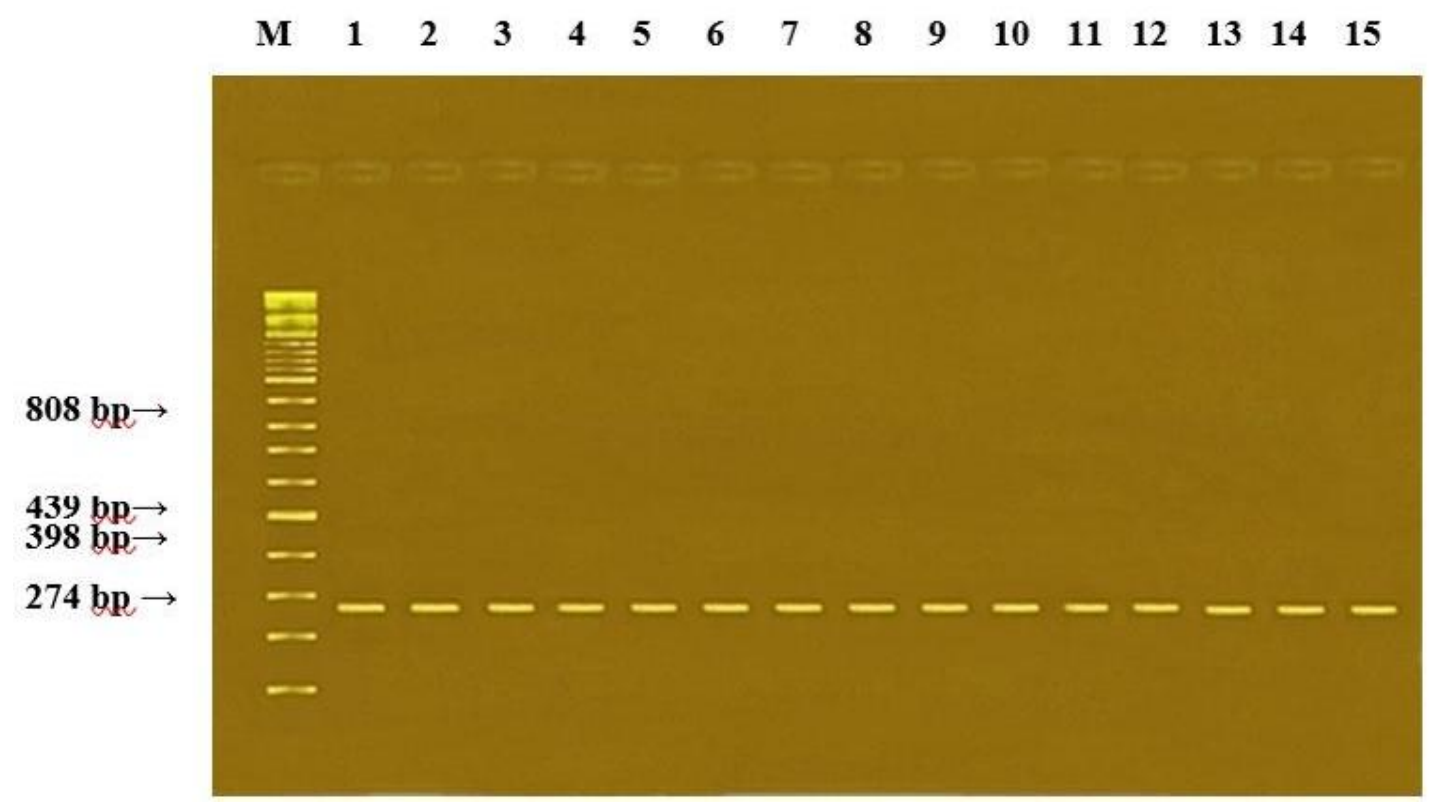

Photograph (3): Agarose gel electrophoresis of multiplex PCR of cyt $b$ gene for cattle (274 bp), pig (398 bp), equine (439 bp) an dog meat (808 bp) for demonstration of minced meat adulteration at processing plant.

Lanes from 1 to 15: Pure cattle meat. 


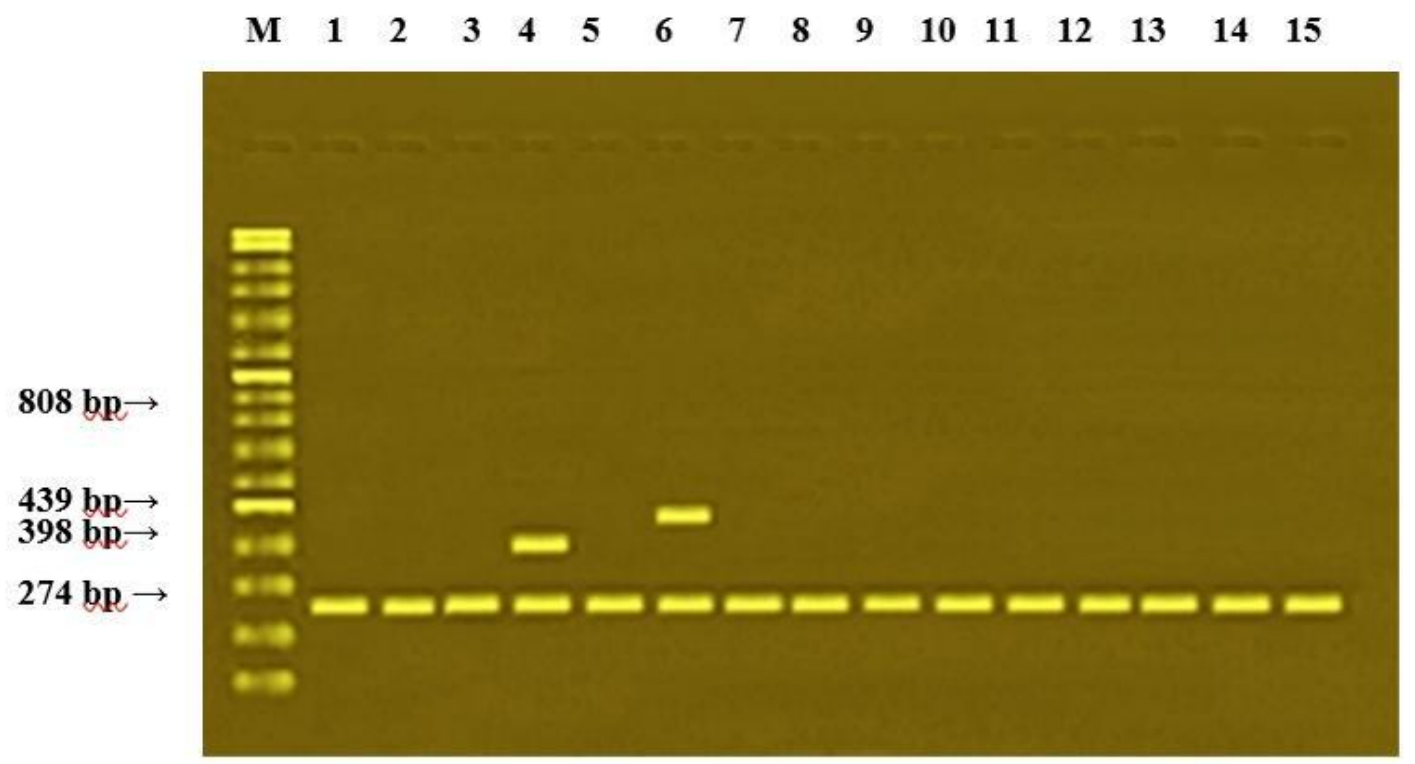

Photograph (3): Agarose gel electrophoresis of multiplex PCR of cyt $b$ gene for cattle (274 bp), pig (398 bp), equine (439 bp) and dog meat (808 bp) for demonstration of sausage adulteration at processing plant.

Lanes 1, 2, 3, 5, 7, 8, 9, 10, 11, 12, 13, 14 \& 15: Pure cattle meat.

Lane 4: Cattle meat intermixed with pig one.

Lane 6: Cattle meat intermixed with equine one.

\section{DISCUSSION}

In photograph (1), application of PCR technique for detection of adulteration of minced meat samples purchased from butcher shops given, 11 samples $(73.33 \%)$ were not adulterated and $4(26.67 \%)$ were adulterated and divided as $3(20 \%)$ and $1(6.67 \%)$ were adulterated by addition of mixture of cattle and equine meat and by addition of pure equine meat, respectively.

In photograph (2), application of PCR technique for detection of adulteration of sausage samples purchased from butcher shops given, 11 samples $(73.33 \%)$ were not adulterated and $4(26.67 \%)$ were adulterated and divided as $1(6.67 \%)$ and $3(20 \%)$ were adulterated by addition of mixture of cattle and equine meat and by addition of pure equine meat, respectively.

In photograph (3), application of PCR technique for detection of adulteration of minced meat samples purchased from processing plants given, all 15 samples $(100 \%)$ were not adulterated and no adulteration presented.

In photograph (4), application of PCR technique for detection of adulteration of sausage purchased from processing plants given ,13 samples (86.67\%) were not adulterated and 2(13.33\%) were adulterated and divided as 1(6.67\%) and 1(6.67\%) were adulterated by addition of mixture of cattle and pig meat and by addition of mixture of cattle and equine meat, respectively. 
The target genes and DNA fragments used as markers for identifying meat species mainly come from the mitochondrial genome, including $12 \mathrm{~S}$ rRNA gene (Wang et al., 2010), 16S rRNA gene (Mitani et al., 2009),18S rRNA gene (Kesmen et al., 2007), cytochrome b gene (Murugaiah et al., 2009), actin gene, cytochrome oxidaseII gene (Singh and Neelam, 2011), NADH dehydrogenase 5/6 (Unajak et al., 2011) and the mtDNA control region (Dooley et al., 2004).

Food manufacturers or food processing factories may add different types of meats to species-specific meat product so as to add bulk or make up the volume of the product. Low priced or lower valued meat species may substitute higher valued meat species. These meat products which contain less desirable species may cause health risk and species identification is becoming a common and important practice (Ong et al., 2007 and Ali, 2008).

Mixing of different species followed by grinding and/or heat-processing aids to the difficulties of discrimination of meat origin and limits the detectability of many analytical techniques.

Fraudulent substitutions of expensive meat with cheaper one or addition of undeclared species in meat products may cause concerns for consumer protection and other economic reasons. El-Shewy, (2007) examined samples of kabab, grilled kofta and meat loaves and he found that equine meat was present in all samples.

PCR analysis of species-specific mitochondrial DNA sequences is the most common method currently used for identification of meat species in food (Ahmed and Abdel-Rahman, 2007).

It was noticed that the sensitivity and accuracy of PCR in detection of species of meat and its adulteration greatly overcome potency of AGID test as PCR depends on the detection of the specific DNA molecules which is a relatively stable allowing analysis of processed and heat treated food products (Beneke and Hagen, 1998 and Abd El-Nasser et al., 2010). Failure of AGID to detect species adulteration may be attributed to addition of spices, salts and another ingredient (Hsieh et al., 1996). Species identification in heat processed products is hindered by progressive denaturation of the protein markers, leading to loss of solubility and antigenicity (Hitchcock and Crimes, 1985).

The current study concluding that the majority of the examined samples of meat products especially minced meat and sausage sold in menufia governorate were adulterated by other animal tissues and equine meat. So, this study assured that adulteration of meat and its products is a dangerous and worldwide problem which violates food labeling laws so, must apply reliable and scientifically accepted tests for detecting that adulteration. Actually, applications of PCR technique were reliable, easier, faster and relatively stable for detection of meat adulteration compared with other trials.

The information suggests that PCRRFLP are useful tools for detecting food adulteration, depending on the processed food chosen, and will help to protect consumers' rights by enabling the 
enforcement of labelling regulations in a country, so we recommend continuous screening of meat products for adulteration in local markets and restaurants should be applied under veterinary authority. Similar issue should be done for imported meat and meat products. Education of consumers is the keystone of the effective control of meat adulteration. Then consumers should purchase their requirement of meat and meat products from known trusted shops and restaurants.

\section{REFERENCES}

Abdulmawjood, A.; Schnenbrucher, H.; Bulte, M., 2003. Development of a Polymerase Chain Reaction System for the Detection of Dog and Cat Meat in Meat Mixtures and Animal Feed. Journal of Food Science, 68: 17571761.

Ahmed, M.M.M.; Abdel-Rahman, S.M., 2007. Application of species-specific polymerase chain reaction and cytochrome $b$ gene for different meat species authentication. Biotechnology, 6:426-430.

Ali-Wafaa, A., 2008. Identification of some animal species through examination of fresh and frozen meat. M. V. Sc. thesis, Department of Forensic medicine and veterinary toxicology, Faculty of Vet. Med., Assiut University, Egypt.

Anderson, S., Bruijin, M.H.L.; Coulson, A. R.; Eperon, I.C.; Snager, F.; Young, I.G., 1982. Complete sequence of cattle mitochondrial DNA. Complete features of the mammalian mitochondrial genome. J. of Mol. Bio. 156:683-717.
Association of Official Analytical Chemists (AOAC), 1996. Official methods of analysis. Association of Official Analytical Chemists. 15th Ed. 540, Benjamin Franklin Station, Washington, U.S.A.

Ballin, N.Z., 2010. Authentication of meat and meat products Department of Food Chemistry, Regional Veterinary and Food Control Authority. Danish Veterinary and Food Administration, Soendervang 4, DK-4100 Ringsted, Denmark Department of Food Science, Faculty of Life Sciences, University of Copenhagen, Rolighedsvej 30, DK1958 Frederiksberg C, Denmark abstract Meat Science 86 (2010) 577587.

Beneke, B.; Hagen, M., 1998. Applicability of PCR (Polymerase chain reaction) for the detection of animal species in heated meat products. Fleischwirtschaft, 78,1016-1019.

Desjardins, P.; Morais, R., 1991. Sequence and gene organization of chicken mitochondrial genome: A novel gene order in higher vertebrates. J. of Mol. Biol., 212: 599-634.

Dooley, J.; Paine, E.; Garrett, D.; Brown, M., 2004. Detection of meat species using TaqMan real-time PCR assays. Meat Sci. 2004; 68: 431-438.

El-Shewy, E.A. 2007. Identification of meat species in some "Ready to eat" meat products sold in Egyptian markets, Zag.Vet.J.35,2:10-18.

El-Shewy-Elham, 2007. Identification of meat species in some ready to eat meat 
products sold in Egyptian markets. Forensic Med. And Toxicology Dept. Fac. Vet. Med. Benha, Univ. Zag. Vet. J., 35(2):10-18.

Hitchcok, C.H.S.; Crimes, A.A., 1985. Methodology for meat species identification: A review. Meat Sci., 15: 215-228.

Irwin, D.M.; Kocher, T.D.; Wilson, A.C., 1991. Evolution of the cytochrome b gene of mammals. J. of Mol. Evo.,32: 128-144.

Jain, Shally; Brahmbhatt, M.N.; Rank, D.N.; Joshi, C.G.; Solanki, J.V., 2007. Use of cytochrome b gene variability in detecting meat species by multiplex PCR assay. Journal of Animal Science in press.

Kesmen Z.; Sahin F.; Yetim H., 2007. PCR assay for the identification of animal species in cooked sausages, Meat Science 77 (2007) 649-653.

Kesmen, Z.; Yetim, H.; Sahin, F. 2006. PCR assay for the identification of animal species in Turkish fermented sausages. In 1st Egyptian-Jordanian conference on biotechnology and sustainable development: Current status and future scenarios, 11-14 December (pp. 151155), Cairo, Eygpt.

Mackie, T.J.; McCartney, J.E. 1996. Medical microbiology and immunology. 1st ed., Churchill Livingston, Edinburgh, London, UK.

Matsunaga, T.; Chikuni, K.; Tanabe, R.; Muroya, S.; Shibata, K.; Yamada, J., 1999. A quick and simple method for the identification of meat species and meat products by PCR assay. Meat Sci., 51 (2): 143-148.

Matsunaga, T.; Chikuni, K.; Tanabe, R.; Muroya, S.; Shibata, K.; Yamada, J.; Shinmura, Y., 1999. A quick and simple method for the identification of meat species and meat products by PCR assay. Meat Science 51: 143-48.

Murugaiah, C.; Noor, M.; Mastakim, M.; Bilung, M.; Selamat, J.; Radu, S., 2009. Meat species identification and Halal authentication analysis using mitochondrial DNA. Meat Sci. 2009; 83: 57-61.

Obrovska, I.; Steinhauserova; Nebola, M., 2002. The application of the PCR method to the identification of meat species. Folia Veterinaria, 46: 113-18.

Ong, S.B.; Zuraini, M.I.; Jurin, W.G.; Cheah, Y.K.; Tunung, R.; Chai, L.C.; Haryani, Y.; Ghazali, F.M.; Son, R., 2007. Meat molecular detection: Sensitivity of polymerase chain reaction-restriction fragment length polymorphism in species differentiation of meat from animal origin. ASEAN Food Journal, 14: 5159.

Pearson, D., 1984. Chemical analysis of food. 8th ed., publishing Co., Churchill Livingston, Edinburgh, London, UK.

Singh, P.; Neelam, S., 2011. Meat species specifications to ensure the quality of meat: a review. International Journal of Meat Science. 2011; 1: 15-26.

Singh, V.; Sachan, N., 2009. Laboratory Manual of Abattoir Practices and 
Detection of adulteration in some traditional processed meat products with equine meat

Animal By-products Technology.

DUVASU, Mathura. 2009; 25-35.

Unajak, S.; Meesawat, P.; Anyamaneeratch, K.; Anuwareepong, D.; Srikulnath, K.; and Choowongkomon, K., 2011. Identification of species (meat and blood samples) using nested-PCR analysis of mitochondrial DNA. Afr. J. Biotechnol. 2011; 10 (29): 5670-5676. 